\title{
A simple model for solid oxide fuel cells
}

\author{
Ghzzai Almutairi ${ }^{1}$ (1)
}

Received: 11 October 2020 / Accepted: 21 October 2020 / Published online: 12 November 2020

(c) The Author(s) 2020

\begin{abstract}
It is widely accepted that solid oxide fuel cells (SOFCs) represent a promising energy conversion approach that deliver a myriad of benefits including low environment pollution, high efficiency, and system compactness. This paper describes the construction of a basic model based on ohmic considerations, mass transfer, and kinetics that can effectively evaluate the performance of small button SOFCs. The analysis of the data indicates that there is a close alignment between the cell potential calculated using the model and previous experimental data. As such, it can be concluded that the model can be employed to optimize, evaluate, or control the design parameters within a SOFC system.
\end{abstract}

Keywords Solid oxide fuel cells $\cdot$ Mathematical models $\cdot$ Mass transfer $\cdot$ Kinetics $\cdot$ Ohmic resistance $\cdot$ Cell potential

\section{Introduction}

In the contemporary era, fuel cell science and technology has evolved into a multidisciplinary discipline that consists of a range of fields including physics, mechanical engineering, molecular chemistry, computational science, electrochemistry and interfacial science, among others. The ultimate aim of many studies in this domain is to develop new and reliable systems of sustainable energy $[1,2]$.

Fuel cells electrochemically convert the chemical energy that is stored in a given fuel into electrical energy. The main difference between fuel cells and batteries are that fuel cells can provide an uninterrupted power supply, while batteries can only function for a limited period of time [3]. Unlike combustion engines, fuel cells are not limited by Carnot cycle, which offers a maximum efficiency of around $40 \%$. In fact, fuel cells can achieve an efficiency level of around $65 \%$ [4-6].

At the start of the twentieth century, the temperature of the curvature globe had increased by around $0.6 \%$ and 2012 saw one of the highest temperatures on record. Phenomenon such as these have led to global warming concerns, and there is now a worldwide focus on reducing carbon dioxide emissions. One prominent source of such emissions is

Ghzzai Almutairi

gmotari@kacst.edu.sa

1 Water and Energy Research Institute, KACST, Riyadh, Saudi Arabia the combustion engine, and efforts are increasingly being invested in studies that seek to find viable and cost-effective methods of replacing this source of energy. One area that has proven to be particularly promising is fuel cell technology $[7,8]$.

SOFCs are comparable to primary cells in that they are also formed of two electrodes, an anode and a cathode, with an electrolyte sandwiched between the two electrodes [9]. Fuel cells are typically classified according to the electrolyte material properties; however, they can also be categorized according to temperature: low-temperature fuel cells and high-temperature fuel cells. Low-temperature fuel cells operate at a temperature of between $30^{\circ} \mathrm{C}$ and $250{ }^{\circ} \mathrm{C}$, and there are five types of these cells: Alkaline fuel cell fuel cells (AFCs), Proton exchange membrane fuel cells (PEMFCs), Direct methanol fuel cells (DMFCs), Direct formic acid fuel cells (DFAFCs) and Solid acid fuel cells (SAFCs), while high-temperature fuel cells operate between $600{ }^{\circ} \mathrm{C}$ and $1000{ }^{\circ} \mathrm{C}$ and there are three types of these cells: solid oxide fuel cells (SOFCs), proton ceramic fuel cells (PCFCs), and molten carbonate fuel cells (MCFCs) [10-12]. In recent years, a significant amount of research effort has been invested in better understanding and addressing the challenges associated with the practical use and commercialization of SOFCs.

The performance of SOFCs is directly impacted by a range of different factors including material composition, fuel stoichiometrics, and geometry. Numerical simulations can be employed to solve complicated problems [13]. As a 
result of the great strides that have been made in terms of increased computation power and simulation efficiency in recent years, software applications and models have emerged that can be used to verify the effects that various factorsincluding fuel composition, fuel float rate, anode pressure, cathode strain, and temperature- - have on the overall performance of a given fuel cell $[14,15]$.

Previous studies $[16,17]$ resulted in the generation of experimental data that modeled the performance of a small button SOFC based on the use of $\mathrm{La}_{0.65} \mathrm{Sr}_{0.3} \mathrm{MnO}_{3}$ and $\mathrm{La}_{0.8} \mathrm{Sr}_{0.2} \mathrm{MnO}_{3}$ nanoceramic powders as cathode materials, yttria-stabilized zirconia, YSZ as cell electrolyte, and $\mathrm{NiO}-\mathrm{YSZ}$ as anode material. The outputs revealed that a

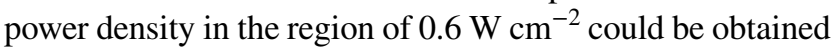
at a current density of $0.85 \mathrm{~A} \mathrm{~cm}^{-2}$ at $0.7 \mathrm{~V}$ and $800{ }^{\circ} \mathrm{C}$ with $1.8 \mathrm{~L} \mathrm{~min}^{-1}$ hydrogen and $0.6 \mathrm{~L} \mathrm{~min}^{-1}$ oxygen. There is now a requirement to model the performance of the cell at different current densities, flow rates, and temperatures.

A number of models of varying complexities have been developed for SOFCs [18-21]. The models that have emerged are typically concerned with ionic transport, mass transport, and electrode kinetics. These models typical facilitate efforts in the areas of SOFC design, optimization, and control.

In previous articles $[16,17]$ which presented same experimental data for the performance of a small button solid oxide fuel cell, SOFC, based on using $\mathrm{La}_{0.65} \mathrm{Sr}_{0.3} \mathrm{MnO}_{3}$ and $\mathrm{La}_{0.8} \mathrm{Sr}_{0.2} \mathrm{MnO}_{3}$ nanoceramic powders as cathode materials, yttria-stabilized zirconia, YSZ, as cell electrolyte and NiO-YSZ as anode material. It was possible to obtain a power density around $0.6 \mathrm{~W} \mathrm{~cm}^{-2}$ at a current density of $0.85 \mathrm{~A} \mathrm{~cm}^{-2}$ at $0.7 \mathrm{~V}$ at $800{ }^{\circ} \mathrm{C}$ with $1.8 \mathrm{~L} \mathrm{~min}^{-1}$ hydrogen and $0.6 \mathrm{~L} \mathrm{~min}^{-1}$ oxygen. Further development requires modeling the cell performance at varying conditions of temperatures, flow rates and current densities.

Several models have been presented for solid oxide fuel cells [18-21] ranging in complexity from zero-dimensional models. Modeling was generally based on electrode kinetics, mass transport and ionic transport in the electrolyte media. These models are generally needed for design, sealing-up, optimization and control.

\section{Mathematical model}

On a basic level, when a fuel cell is connected to an external load, the difference potential across the electrodes within the cell pushes the electrons through an external circuit. However, the underlying processes that form the electrochemical system are relatively complex. While several researchers have focused on the charge transfer that takes place at the interfaces that are formed by the electrolyte and electrodes, understanding in this area remains limited. The operation of SOFCs involves a range of irreversibilities that can lead to different losses. The total resistance of electrodes is influenced by four aspects: concentration polarization resistance, the contact resistance, the internal resistance, and the activation polarization resistance. The internal resistance indicates the electron transport resistance, which is typically measured according to the thickness of the electrode structure and the electronic conductivity. Contact resistance is influenced by the level of contact between the electrolyte structure and the electrode. All restrictive losses represent functions of the local current density. It is possible to reduce potential losses using an appropriate material for the electrode and ensuring that the micro-structural properties of the cells are carefully controlled throughout the manufacturing process.

Our present model is based on the well-known equation of cell potential [18]

$V_{\text {cell }}=V_{\text {Nernest }}-\eta_{\text {ohm }}-\eta_{\text {act }}-\eta_{\text {dif }}=f(i)$,

where $\mathrm{V}_{\text {cell }}$ is the cell voltage, $\mathrm{V}_{\text {Nernest }}$ is the Nernest potential, $\eta_{\text {ohm }}$ is the ohmic polarization, $\eta_{\text {act }}$ is the activation polarization and $\eta_{\text {dif }}$ is the diffusion polarization and $i$ is the cell current. Since it has already actual measurements of open-circuit potentials $\mathrm{V}_{\text {ocp }}$ at different conditions, it can use these instead of $V_{\text {Nernest }}$ Therefore, Eq. (1) will be replaced by the following equation

$V_{\text {cell }}=V_{\text {ocp }}-\eta_{\text {ohm }}-\eta_{\text {act }}-\eta_{\text {dif }}$.

The polarization contributions can be estimated as follows:

\section{Ohmic polarization}

The cell ohmic resistance is the sum of anode, cathode and electrolyte resistances, $R_{\text {an }}, R_{\text {cat }}$ and $R_{\text {el, }}$ respectively. Each is calculated from Ohm's second law

$R i=\frac{\sigma i \delta i}{A}$,

where $R i$ is the resistance contribution of each part, $\sigma i$ is the specific resistivity, $\delta i$ is each part thickness and A is the area. As for the electrolyte, the contribution of ionic and electronic resistivities can be estimated from the following equation

$\frac{1}{\text { Rel }}=\frac{1}{\text { Rion }}+\frac{1}{\text { Relec }}$.

The ionic conductivity of the cell electrolyte is around $0.2 \mathrm{~S} \mathrm{~m}^{-1}$ [22]. The thickness and electronic resistivities as 
Table 1 Characteristics of cell components

\begin{tabular}{lll}
\hline Component & Thickness, $\mu$ & Specific resistivity, $\Omega \mathrm{m}^{*}$ \\
\hline Anode & 1500 & $2.98 \times 10^{-5} \exp (-1392 / \mathrm{T})$ \\
Cathode & 50 & $8.11 \times 10^{-5} \exp (600 / \mathrm{T})$ \\
Electrolyte & 15 & $2.94 \times 10^{-5} \exp (10,350 / \mathrm{T})$ \\
\hline
\end{tabular}

*Reference (18)

a function of temperature $\mathrm{T}$ in ${ }^{\mathrm{o}} \mathrm{K}$ of each of the cell components is shown in Table 1.

\section{Activation polarization}

Activation polarization for simple electrode kinetics is usually expressed by the Butler-Volmer equation [18]

$i=i_{o}\{\exp (\alpha-\exp [-(1-\alpha)]\}$,

where $\alpha$ is the transfer coefficient, usually taken as $0.5, \mathrm{R}$ is the universal gas constant $=8.314 \mathrm{~J} \mathrm{~mol}^{-1}{ }^{\mathrm{o}} \mathrm{K}$ and $\mathrm{i}_{\mathrm{o}}$ is the exchange current. The exchange currents are estimated from the following equations [18]

$\mathrm{i}_{\mathrm{o}, \mathrm{an}}=0.25 \gamma_{\mathrm{an}} \mathrm{A} \exp \left(\frac{-E a c t, a n}{R T}\right)$,

$\mathrm{i}_{\mathrm{o}, \mathrm{an}}=0.25 \gamma_{\text {cath }} \mathrm{A} \exp \left(\frac{-E a c t, \text { cath }}{R T}\right)$,

where $\mathrm{E}_{\text {act }}$ is the activation energy for each electrode reaction in $\mathrm{J} \mathrm{mol}^{-1} \cdot \gamma_{\text {an }}$ and $\gamma_{\text {cath }}$ are $7 \times 10^{9} \mathrm{~A} \mathrm{~m}^{-2}$ and $\mathrm{E}_{\text {act,an }}$ and $\mathrm{E}_{\text {act,cath }}$ are 110 and $120 \mathrm{~kJ} \mathrm{~mol}^{-1}$, respectively [18].

For small over potentials less than $20 \mathrm{mV}$, the above equations reduce to the following linear equation:

$\eta_{\mathrm{act}}=\frac{R T}{n F i o}$

and for high over potentials $>100 \mathrm{mV}$, the equation reduces to the Tafel equation:

$\eta_{\text {act }}=\frac{R T}{\alpha n F} \ln \frac{i}{i o}$.

\section{Diffusion polarization}

The diffusion polarization is estimated from the following equation [21]:

$\eta_{\mathrm{dif}}=\frac{R T}{n F} \ln \left(1-\frac{i}{i L}\right)$

where $\mathrm{i}_{\mathrm{L}}$ is the limiting current estimated from overall mass transfer coefficient

$\mathrm{i}_{\mathrm{L}}=\mathrm{nFK}_{\mathrm{ov}} \mathrm{CA}$,

where $\mathrm{C}$ is the molar concentration of the reactant, $\mathrm{K}_{\mathrm{ov}}$ is the combination between the mass transfer coefficients in the gas space above each electrode $\mathrm{K}_{\mathrm{g}}$, and in the porous electrode $\mathrm{K}_{\mathrm{p}}$ according to the equation

$\frac{1}{K o v}=\frac{1}{K g}+\frac{1}{K p}$.

$\mathrm{K}_{\mathrm{g}}$ in turn can be calculated from the following correlation for laminar gas flow over flat surface [8]

$\mathrm{Sh}=0.648(\mathrm{Re})^{0.5}(\mathrm{Sc})^{1 / 3}$,

where Sh is Sherwood number, $\frac{K g d}{D}$, Re is Reynold's number $\frac{\rho \mathbf{V d}}{\mu}$, and $\mathrm{Sc}$ is Schmidt number, $\frac{\mu}{\mathbf{\rho D}}$.

Here, $\mathrm{d}$ is the alumina tube diameter, $\mathrm{V}$ is the velocity, $\mu$ is the gas viscosity, $\rho$ is the gas density, and $D$ is the molar diffusivity of $\mathrm{H}_{2}$ or $\mathrm{O}_{2}$ is the gas phase.

On the other hand $\mathrm{K}_{\mathrm{p}}$ is estimated as $\frac{\epsilon D}{\delta}$ [23], where $\epsilon$ is the electrode porosity.

Gas densities are calculated from the ideal gas law

$\rho=\frac{P M}{R T}$

where $\mathrm{P}$ is the absolute pressure and $\mathrm{M}$ is gas molecular weight, $\mathrm{O}_{2}$ and $\mathrm{H}_{2}$ viscosities are obtained from ref [24]. The molar diffusivities of $\mathrm{O}_{2}$ and $\mathrm{H}_{2}$ are calculated from the following equation [25]:

$D A B=\frac{10^{(-4)}\left(1.084-0.249 \sqrt{\frac{1}{\mathrm{MA}}+\frac{1}{\mathrm{MB}}}\right) T^{(3 / 2)} \sqrt{\frac{1}{\mathrm{MA}}+\frac{1}{\mathrm{MB}}}}{\operatorname{Pr}_{A B}^{2} f\left(K T / \varepsilon_{A B}\right)}$
Table 2 Physical properties of cathode and anode gases

\begin{tabular}{|c|c|c|c|c|c|c|}
\hline \multirow[t]{2}{*}{ Temp ${ }^{\circ} \mathrm{C}$} & \multicolumn{2}{|l|}{$\rho, \mathrm{Kg} / \mathrm{m}^{3}$} & \multicolumn{2}{|c|}{$\mu, \mathrm{kg} / \mathrm{ms} \times 10^{5}$} & \multicolumn{2}{|c|}{$\mathrm{D}, \mathrm{m}^{2} / \mathrm{s} \times 10^{5}$} \\
\hline & Cathode & Anode & Cathode & Anode & Cathode & Anode \\
\hline 700 & 0.200 & 0.025 & 4.674 & 1.848 & 15.17 & 59.11 \\
\hline 750 & 0.190 & 0.024 & 4.819 & 1.901 & 18.30 & 63.70 \\
\hline 800 & 0.182 & 0.023 & 4.961 & 1.953 & 19.91 & 68.45 \\
\hline
\end{tabular}


Table 3 Characheristics of the experimental cell

\begin{tabular}{ll}
\hline Alumina tube diam, $\mathrm{m}$ & 0.03 \\
Electrodes porosity, dimensionless & 0.28 \\
Electrode area, $\mathrm{m}^{2}$ & $1.13 \times 10^{-4}$ \\
\hline
\end{tabular}

Table 4 Cell Potential breakdown in Volts

\begin{tabular}{ll}
\hline $\mathrm{V}_{\text {ocp }}$ & 1.14 \\
\hline$\eta_{\text {ohm }}$ & 0.104 \\
$\eta_{\text {act }}$ & 0.244 \\
$\eta_{\text {dif }}$ & 0.073 \\
$\mathrm{~V}_{\text {cell }}$ & 0.719 \\
\hline
\end{tabular}

where $r_{A B}$ and $f\left(K T / \varepsilon_{A B}\right)$ are given in tabulated forms in ref [25]. Table 2 summarizes the physical properties for $\mathrm{O}_{2}$ and $\mathrm{H}_{2}$ at the given test temperatures.

\section{Results and discussions}

The modeling and simulation of the anode supported planar type of Solid Oxide Fuel Cell was carried out using the equation for calculating the SOFC cell voltage. Testing the model in estimating the cell potential, we selected the conditions of current density of $0.85 \mathrm{~A} \mathrm{~cm}^{-2}$, cell temperatures of $800{ }^{\circ} \mathrm{C}, \mathrm{H}_{2}$ flow rate of $1.8 \mathrm{~L} \mathrm{~min}^{-1}$ and $\mathrm{O}_{2}$ flow rate of $0.6 \mathrm{~L} \mathrm{~min}^{-1}$. Table 3 summarizes the cell potential breakdown, which is calculated from the above equations.

For comparison, the measured $\mathrm{V}_{\text {cell }}$ at these conditions was $0.7 \mathrm{~V}$. This shows that the model in spite of its simplicity estimates the cell potential with reasonable accuracy. The model as such can be used for optimization, control, or investigating of the effects of design parameters on the cell performance (Table 4).

\section{Conclusion}

The goal of this research work is to create a solid oxide fuel cell model and apply the model to analyze the cell 's output by varying various parameters. As there is a direct relation between SOFC design parameters and the performance of a SOFC, it is possible to improve the performance of the cell by optimizing the design parameters. The improved performance of the newly established SOFC model, which can be further strengthened by changing the pressure and thickness of the cell components, is also verified by higher cell power values, average current density and efficiency.
Open Access This article is licensed under a Creative Commons Attribution 4.0 International License, which permits use, sharing, adaptation, distribution and reproduction in any medium or format, as long as you give appropriate credit to the original author(s) and the source, provide a link to the Creative Commons licence, and indicate if changes were made. The images or other third party material in this article are included in the article's Creative Commons licence, unless indicated otherwise in a credit line to the material. If material is not included in the article's Creative Commons licence and your intended use is not permitted by statutory regulation or exceeds the permitted use, you will need to obtain permission directly from the copyright holder. To view a copy of this licence, visit http://creativecommons.org/licenses/by/4.0/.

\section{References}

1. Andersson, M. Sunden, B.: Solid oxide fuel cell material structure grading in the direction normal to the electrode/electrolyte interface using COMSOL Multiphysics, COMSOL Conference Cambridge, (2014).

2. Andersson, M.: Solid Oxide Fuel Cell Modeling at the Cell Scale, Doctoral dissertation Lund University, 9789174731804, (2011).

3. Maja, H., Palma, L.: Design of a Wide Input Range DC-DC Converter with Digital Control Scheme for Fuel Cell Power Conversion. IEEE Trans. Industr. Electron. 3, 1247-1255 (2008)

4. Yingcai Huang, Y. et al.: Evaluation of the waste heat and residual fuel from the solid oxide fuel cell and system power optimization. Int. J. Heat Mass Tran. 115, 1166-1173 (2017).

5. Stambouli, A., Traversa, E.: Fuel cells, an alternative to standard sources of energy. Renew. Sustain. Energy Rev. 6(3), 295-304 (2002a)

6. Odeh, N., Cockerill, T.: Life cycle GHG assessment of fossil fuel power plants with carbon capture and storage. Energy Pol. 36(1), 367-380 (2008)

7. National Oceanic and Atmosphere Administration, Annual Review Global Climate Report, (December 2013).

8. Stambouli, A., Traversa, E.: Solid oxide fuel cells (SOFCs): a review of an environmentally clean and efficient source of energy. Renew. Sustain. Energy Rev. 6(5), 433-455 (2002b)

9. Andersson, M. Paradis, H. Yuan, J. Sunden, B.: Catalyst materials and catalytic steam reforming reactions in SOFC anodes. International Green Energy Conference, (2010).

10. Raza, R.A., Javed, N., Rafique, M., Ullah, A., Ali, K., Saleem, A., Ahmed, M., R. : Fuel cell technology for sustainable development in Pakistan-An over-view. Renew. Sustain. Energy Rev. 53, 450-461 (2016)

11. Khan, B.: Non-conventional Energy Resources, Tata McGraw-Hill Education, 2006.

12. Kirubakaran, A., Jain, S., Nema, R.: A review on fuel cell technologies and power electronic interface. Renew. Sustain. Energy Rev. 13(9), 2430-2440 (2009)

13. Gamble, S.: Fabrication microstructure performance relationships of reversible solid oxide fuel cell electrodes review. Mater. Sci. Technol. 27(10), 1485-1497 (2011)

14. Wolfgang, G., Bessler, A.: new computational approach for SOFC impedance from detailed electrochemical reaction-diffusion models. Solid State Ionics 176, 997-1011 (2005)

15. Zuopeng, Q., et al.: Three-dimensional computational fluid dynamics modeling of anode-supported planar SOFC. Int. J. Hydrogen Energy 36(16), 10209-10220 (2011)

16. Almutairi, G. Alyousef, Y. Alenazey, F. Alnassar, S. Alsmail, H. Ghouse, M.: Electrochemical Characteristics of $\mathrm{La}_{0.65} \mathrm{Sr}_{0.3} \mathrm{MnO}_{3}$ 
and $\mathrm{La}_{0.8} \mathrm{Sr}_{0.2} \mathrm{MnO}_{3}$ Nanoceramic Cathode Powders for Intermediate Temperature Solid Oxide Fuel Cell (SOFC) Application. International Journal of Electrochemical Science, 12 8148-8166 (2017).

17. Almutairi, G. Alenazey, F. Alyousef, Y. Alshammari, B.: Alanine assisted synthesis and characterization of $\mathrm{La}_{0.65} \mathrm{Sr}_{0.3} \mathrm{MnO}_{3}$ (LSM) nanocrystalline cathode powders for solid oxide fuel cells (SOFCs). International Journal of Electrochemical Science 12, 11616-11632 (2017).

18. Campanari, S. lora, P.: Definition and sensitivity analysis of a finite volume SOFC model for a tubular cell geometry. Journal of Power Sources 132, 113-126 (2004).

19. Janardhanan, V., Deutschmann, O.: Modeling of Solid-Oxide Fuel Cells. Zeitschrift fur, physikalische chemie 221, 443-478 (2007)
20. Kakac, S., Pramuanjaroenkij, A., Zhou, Z.: A review of numerical modeling of solid oxide fuel cells. Int. J. Hydrogen Energy 32, 761-786 (2007)

21. Perez, L. Suarez, L. Ledon,Y. Garcia,J.: International Scholarly Research Network Chemical Engineering, (2012) 1-6.

22. J.Stortedler, J.: Ionic Conductivity in Yttria-Stabilized Zirconia Thin Films, M.S. thesis, University of Twente, the Netherlands (2005).

23. Knudsen, J. Katz, D.: Fluid Dynamics and Heat Transfer, McGraw Hill (1958).

24. Weast, R. (ed.): CRC Handbook of chemistry and physics, 65 th edn. CRC Press, Florida (1984)

25. Treybal, R.: Mass-transfer Operations, $3^{\text {rd }}$ edition, McGraw Hill, (1981). 